\title{
Hidrostatski pogon in samodejni menjalnik na tovornih vozilih
}

Jaša Saražin, Gozdarski inštitut Slovenije, Oddelek za gozdno tehniko in ekonomiko

Objavljeno na spletu 09.01.2022 (https://doi.org/10.20315/IG.2022.0003)

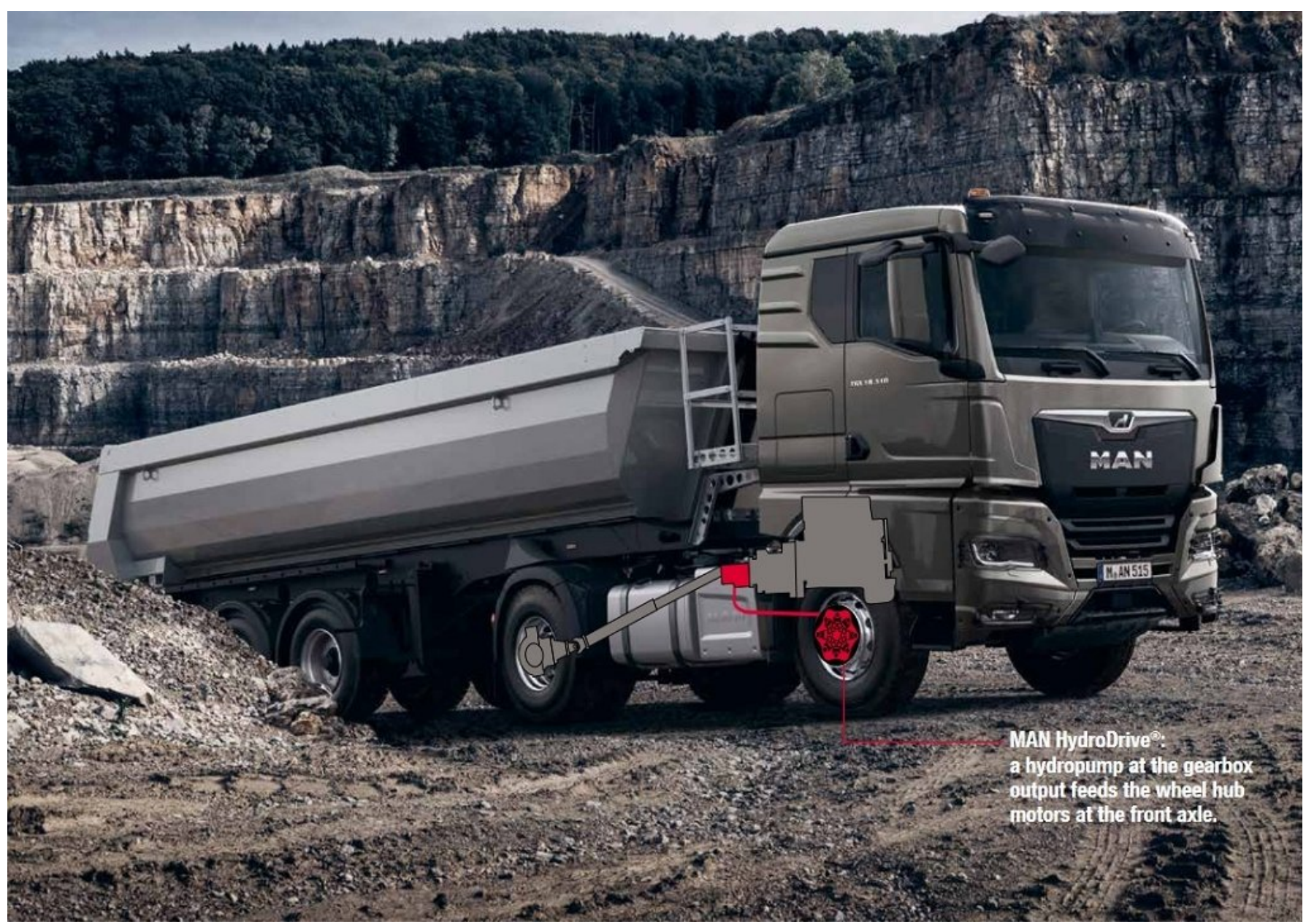

Slika 1: Tovornjak s hidrostatsko gnano prednjo osjo (Vir: www.man.eu)

Nedavno smo se udeležili strokovne konference organizirane s strani revije Intervencija, naslovljene: Razvoj tehnike intervencijskih vozil. Čeprav je bilo na konferenci govora zgolj o intervencijskih vozilih, so bile številne zanimivosti primerne tudi za gozdarska tovorna vozila. Med drugim so bile predstavljene moderne rešitve, ki lajšajo vožnjo tovornjakov po nižje kategoriziranih prometnicah in brezpotjih. 
Hidrostatski pogon, ki ga že vrsto let poznamo pri boljših gozdarskih traktorjih, je že nekaj let na voljo tudi kot dodatna oprema na krmiljeni osi tovornih vozil. Taka vozila imajo klasičen mehanski pogon na zadnjih oseh, ko je potreben pogon na vsa kolesa, pa ločen hidrostatski pogon poganja prednjo os do hitrosti približno $30 \mathrm{~km} / \mathrm{h}$. Prednosti hidrostatskega pogona v primerjavi s klasičnim mehanskim pogonom na isti osi je do $750 \mathrm{~kg}$ nižja teža (oz. zgolj približno $400 \mathrm{~kg}$ večja, če sicer ta os ne bi bila gnana), večji navor, konstantna moč že od nizkih vrtljajev dalje ter nižja poraba goriva v primerjavi z mehanskim pogonom na vsa kolesa (ko pogon na prednji osi ni potreben).

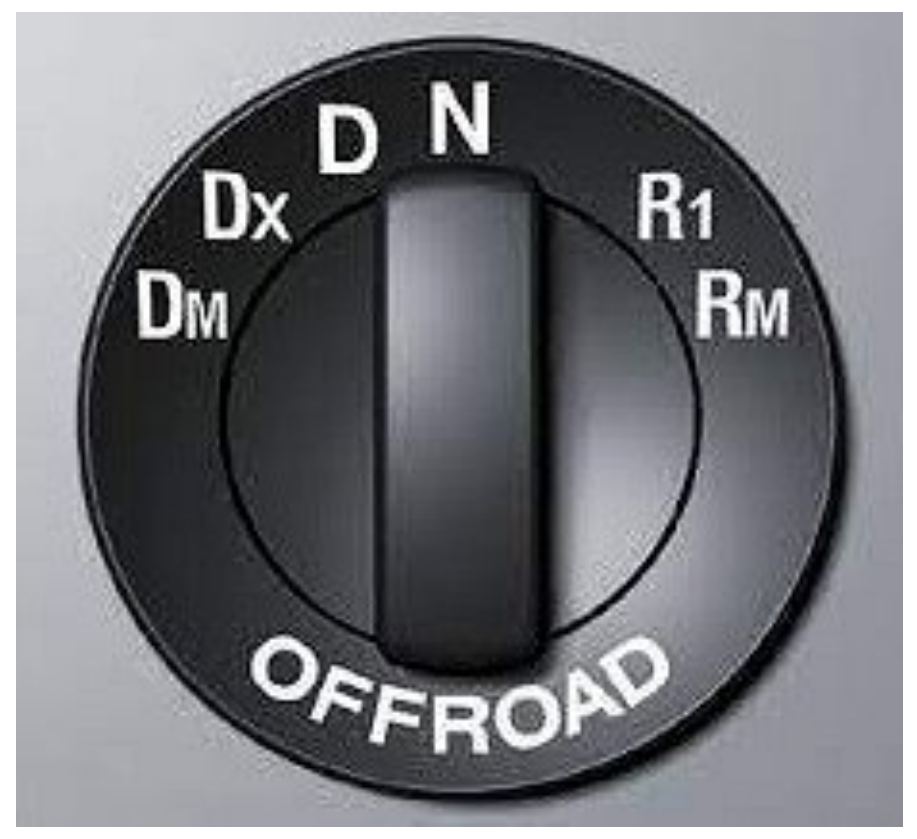

Slika 2: Gumb za izbiro prestavnega programa (Vir: www.man.eu)

Predstavljeno je bilo tudi, da postajajo samodejni menjalniki vedno bolj sofisticirani in prilagojeni vožnji zunaj tlakovanih prometnic, kjer so imeli starejši samodejni menjalniki največ pomanjkljivosti. Številni proizvajalci že ponujajo program vožnje »offroad«, ki vozilu dovoljuje več zdrsavanja koles, vožnjo na višjih obratih, manj prestavljanja in možnost ročnega izbora prestav. 